\title{
JTK-853, a Novel Non-Nucleoside Hepatitis C Virus Polymerase Inhibitor, Demonstrates a High Genetic Barrier to Resistance in vitro
}

\author{
Izuru Ando ${ }^{a}$ Naoki Ogura ${ }^{a}$ Yukiyo Toyonaga ${ }^{a}$ Kunihiro Hirahara ${ }^{b}$ \\ Tsutomu Shibata $^{\mathrm{b}}$ Toru Noguchi ${ }^{\mathrm{a}}$ \\ ${ }^{a}$ Central Pharmaceutical Research Institute, Japan Tobacco Inc., Osaka, and ${ }^{b}$ Clinical Research Planning \\ Department, Japan Tobacco Inc., Tokyo, Japan
}

\section{Key Words}

Hepatitis $\mathrm{C}$ virus $\cdot \mathrm{HCV}$ polymerase inhibitor $\cdot$ Resistance

\begin{abstract}
JTK-853 is a novel, non-nucleoside, palm site-binding hepatitis $\mathrm{C}$ virus ( $\mathrm{HCV}$ ) polymerase inhibitor that has demonstrated antiviral activity in HCV-infected patients during 3 days of treatment. To estimate the genetic barrier of JTK- 853 to resistance in vitro, colony formation assays were conducted using HCV replicon cells (genotypes $1 \mathrm{a}$ and $1 \mathrm{~b}$ ). The colony formation assays revealed that the numbers of resistant colonies for JTK-853 were much lower than those for other direct-acting antivirals, including palm site- or thumb pocketbinding non-nucleoside HCV polymerase inhibitors (NNIs), an NS5A inhibitor (NS5Ai), and a protease inhibitor (PI). Furthermore, the numbers of resistant colonies for JTK-853 in combination with the NS5Ai or PI were lower than those for other combinations of $\mathrm{NS} 5 \mathrm{Ai}+\mathrm{NNI}$, and NS5 Ai + PI. Our findings demonstrate that JTK-853 has a high genetic barrier to resistance, and suggest that its combination therapies will be potent in suppressing the emergence of drug resistance in HCV-infected patients.

Copyright $\odot 2013$ S. Karger AG, Basel
\end{abstract}

\section{Introduction}

Hepatitis C virus (HCV) is a global health concern. Approximately 130 million individuals worldwide are estimated to be infected with HCV [1]. It has been suggested that over $25 \%$ of $\mathrm{HCV}$-infected patients develop liver cirrhosis and hepatocellular carcinoma as consequences of chronic infection with $\mathrm{HCV}[2,3]$. The current standard of care involving treatment with pegylated interferon and ribavirin is not only unsatisfactory for its effectiveness but also unavoidably causes severe side effects. To overcome these problems, many direct-acting antivirals (DAAs) are in clinical trials and some of them (telaprevir and boceprevir) were launched for HCV treatment in 2011. However, when DAAs are used as monotherapies, the emergence of drug-resistant $\mathrm{HCV}$ variants is inevitable for DAA-based therapies, and these variants cause viral breakthroughs [4]. Therefore, new DAAs that show a high barrier to resistance are strongly needed for $\mathrm{HCV}$ treatment. In some current clinical trials, nucleoside HCV polymerase inhibitors (NIs) appear to show a high barrier to resistance compared with other classes of DAAs [5-7].

\section{KARGER}

(๑) 2013 S. Karger AG, Basel

0300-5526/13/0565-0302\$38.00/0

E-Mail karger@karger.com

www.karger.com/int 
The HCV replicon system [8] is useful for drug development, and is widely used for the selection of resistant mutants. In general, when HCV replicon cells are treated with DAAs for over 2 weeks in the presence of Geneticin, DAA-resistant HCV replicon colonies emerge on the surface of the tissue culture plates. Hence, the number of DAA-resistant HCV replicon colonies indicates the genetic barrier to resistance. Therefore, colony formation assays are considered to be useful tools for assessing the genetic barrier of DAAs to resistance [9].

JTK-853 is a novel, non-nucleoside, palm site-binding $\mathrm{HCV}$ polymerase inhibitor that has demonstrated effective antiviral activity in $\mathrm{HCV}$ replicon cells with $\mathrm{EC}_{50}$ values of 0.38 and $0.035 \mu \mathrm{M}$ in genotype $1 \mathrm{a} \mathrm{H} 77$ and $1 \mathrm{~b}$ Con 1 strains, respectively [10]. Furthermore, JTK-853 showed a viral reduction of more than 1 log in $\mathrm{HCV}$-infected patients during 3 days of treatment [11].

The aim of this in vitro study was to evaluate the emergence of JTK-853 resistance in HCV replicon cells. To achieve this, we conducted colony formation assays of JTK-853 alone or in combination with other DAAs, and compared the genetic barrier to resistance with those of other DAAs, such as other non-nucleoside HCV polymerase inhibitors (NNIs), an NI, an NS5A inhibitor (NS5Ai), and a protease inhibitor (PI).

\section{Materials and Methods}

\section{Compounds and Reagents}

JTK-853 [10, 12] was synthesized at Japan Tobacco Inc., Central Pharmaceutical Research Institute (Osaka, Japan). GS-9190 (palm site NNI) [13], PF-868554 (thumb pocket NNI) [14], PSI6130 (NI) [15], BMS-790052 (NS5Ai) [16], and TMC435 (PI) [17] were prepared at Japan Tobacco Inc. according to the published protocols. The thumb pocket NNI-A (indole-derivative NNI) [18, 19] was identified at Japan Tobacco Inc. and described elsewhere. VX-222 (thumb pocket NNI) [20,21] was purchased from Selleck (Houston, Tex., USA). Human serum (HS) was purchased from Gemini Bio-Products (West Sacramento, Calif., USA).

\section{Cells}

Huh-7.5 cells [22] were propagated in high-glucose Dulbecco's modified Eagle's medium (Nikken BioMedical Laboratory, Kyoto, Japan) containing 10\% fetal bovine serum (Moregate Biotech, Bulimba, Australia), $0.1 \mathrm{mM}$ nonessential amino acids (Invitrogen, Carlsbad, Calif., USA), $100 \mathrm{U} / \mathrm{ml}$ penicillin (Invitrogen), $100 \mu \mathrm{g} / \mathrm{ml}$ streptomycin sulfate (Invitrogen), and $2 \mathrm{mM} \mathrm{L}$-glutamine (Invitrogen).

HCV subgenomic replicon-harboring cells of genotype $1 \mathrm{~b}$ Con 1 and genotype 1a H77 strains [8, 22-24] were used to determine the antiviral activity of JTK-853. The HCV subgenome consisting of NS3 to the $3^{\prime}$ untranslated region of the HCV RNA genome was fused with or without luciferase as a reporter gene. All of the replicon cells harbor a selectable marker, neomycin phosphotransferase, that confers Geneticin resistance. The replicon cells were propagated in a medium containing $0.5-1 \mathrm{mg} / \mathrm{ml}$ Geneticin (Invitrogen).

\section{Colony Formation Assay}

The HCV subgenomic replicon RNAs $(4 \mu \mathrm{g})$ of genotype 1a $\mathrm{H} 77$ and $1 \mathrm{~b}$ Con 1 strains $[8,22]$ were individually transfected into Huh-7.5 cells $\left(4 \times 10^{6}\right)$ using a GenePulser (Bio-Rad, Hercules, Calif.,) at $960 \mu \mathrm{F}$ and $270 \mathrm{~V}$. The cells were then seeded in 6 -well plates at a density of $1 \times 10^{5}$ cells/well. Four hours after transfection, the culture medium was removed and replaced with medium containing JTK-853 or other DAAs [prepared in dimethyl sulfoxide (DMSO) and added to a final concentration of $0.1 \%$ (v/v) DMSO], $600 \mu \mathrm{g} / \mathrm{ml}$ Geneticin, and 40\% HS. For treatment with JTK- 853 or DAA alone, each compound was added at $1 \times$ or $1 / 3 \times 90 \%$ effective concentration $\left(\mathrm{EC}_{90}\right)$ in the presence of $40 \%$ HS [4]. For treatment with JTK-853 in combination with another DAA, the compounds were added at $1 / 4 \times \mathrm{EC}_{90}$ in the presence of $40 \% \mathrm{HS}$. The DAA-containing medium was replaced twice weekly. After treatment of the cells for 2-3 weeks, the colonies that emerged in the presence of the DAAs were visualized with crystal violet $[1 \%(\mathrm{v} / \mathrm{v})$ in methanol]. The lysis buffer was prepared as 1:1 mixture of ethanol and the Buffer RLT included in RNeasy RNA extraction kit (Qiagen, Venlo, Netherlands) for measurement of colony number. The colonies were lysed by the lysis buffer, and the resistant colonies were quantified as a measurement of optical density (OD) $595 \mathrm{~nm}$. For the determination of cytotoxicity of JTK-853 or other DAAs, the Huh-7.5 cells were treated with JTK-853 or other DAAs for 2 weeks. The thumb pocket NNI-B and NS5Ai were added at $100 \mu \mathrm{M}$ and $100 \mathrm{nM}$, respectively. JTK-853 and other DAAs were added at $10 \mu \mathrm{M}$. JTK-853- or DAA-containing medium was changed twice a week. Two weeks after the culture, the cells were stained with crystal violet [ $1 \%(\mathrm{v} / \mathrm{v})$ in methanol], and then lysed by the lysis buffer. The cytotoxicity was determined as a measurement of OD $595 \mathrm{~nm}$ of the cell lysates.

\section{Sequence Analysis}

Total RNA was extracted from the JTK-853- and DAA-resistant colonies using an RNeasy RNA Extraction Kit (Qiagen) and the HCV replicon cDNA was reverse-transcribed with a SuperScript III First-Strand Synthesis System (Invitrogen). The NS5B, NS5A, and NS3 genes were amplified by PCR with TaKaRa LA Taq or PrimeSTAR MAX (TaKaRa, Ohtsu, Japan). The primers used for the reverse transcription were 5'-AGAGGCCGGAGTGTTTACCC-3' for genotype $1 \mathrm{a} \mathrm{H77}$ and $5^{\prime}$-TGGAGTGTTTAGCTCCCCGT-3' for genotype $1 \mathrm{~b}$ Con 1 . The primers used for PCR of $\mathrm{H} 77$ were as follows: NS5B, 5'-GGCCGACACGGAAGATG-3' (forward) and 5'-AGAGGCCGGAGTGTTTACCC-3' (reverse); NS5A, 5' -CCTTTGAAAAACACGATAATACC-3' (forward) and 5'-TGACGGCAGCTGTAAAAGCC-3' (reverse), and NS3, $5^{\prime}$-GGCAGTGCAATGGATGAAC-3' (forward) and $5^{\prime}$-CTTCCTCTACGGATAGCAAG-3' (reverse). The primers used for PCR of Con 1 were as follows: NS5B, $5^{\prime}$-GTGAGGACGTCGTCTGCTGC-3' (forward) and 5'-TGGAGTGTTTAGCT CCCCGT-3' (reverse); NS5A, 5' -CCTTTGAAAAACACGATAA TACC- $3^{\prime}$ (forward) and 5'-CCAGGATGTTAAACAGGAGGG$3^{\prime}$ (reverse), and NS3: 5'-CCCTCCTGTTTAACATCCTGG-3' (forward) and 5'-TTCGCCTTCATCTCCTTAG-3' (reverse). 
Table 1. In vitro antiviral activity of JTK-853 in the presence of $40 \% \mathrm{HS}$

\begin{tabular}{lcc}
\hline $\begin{array}{l}\text { Direct-acting } \\
\text { antivirals }\end{array}$ & \multicolumn{2}{l}{$\mathrm{EC}_{90}$} \\
\cline { 2 - 3 } & $1 \mathrm{a}(\mathrm{H} 77)$ & $1 \mathrm{~b}(\mathrm{Con} 1)$ \\
\hline $\mathrm{JTK}-853, \mu \mathrm{M}$ & $6.5 \pm 0.5$ & $0.34 \pm 0.05$ \\
GS-9190, $\mu \mathrm{M}$ & $2.4 \pm 0.5$ & $0.30 \pm 0.04$ \\
$\mathrm{NNI}-\mathrm{A}, \mu \mathrm{M}$ & $0.22 \pm 0.04$ & $0.42 \pm 0.01$ \\
PF-868554, $\mu \mathrm{M}$ & $15 \pm 4$ & $6.4 \pm 0.5$ \\
$\mathrm{VX}-222, \mu \mathrm{M}$ & $0.59 \pm 0.05$ & $0.31 \pm 0.03$ \\
PSI-6130, $\mu \mathrm{M}$ & $6.3 \pm 0.3$ & $6.8 \pm 0.4$ \\
BMS-790052, nM & $1.5 \pm 0.2$ & $0.45 \pm 0.03$ \\
TMC435, $\mu \mathrm{M}$ & $0.42 \pm 0.04$ & $0.17 \pm 0.03$ \\
\hline
\end{tabular}

Data represent mean \pm standard error from four independent experiments.

\section{Results}

Antiviral Activity of JTK-853 in vitro in the Presence of $40 \% \mathrm{HS}$

Prior to performing the colony formation assays, we determined the antiviral activity of JTK- 853 in the presence of $40 \%$ HS. This supplementation of $40 \%$ HS in the culture is thought to be almost equivalent to the physiological concentrations in human blood [10]. When JTK853 was incubated with the replicon cells for $48 \mathrm{~h}$, it showed antiviral activity against genotype $1 \mathrm{a} \mathrm{H} 77$ and $1 \mathrm{~b}$ Con 1 replicon cells with $\mathrm{EC}_{90}$ values of $6.5 \pm 0.5$ and $0.34 \pm 0.05 \mu \mathrm{M}$ (mean \pm standard error), respectively (table 1). The $\mathrm{EC}_{90}$ values of the other DAAs are also shown in table 1.

\section{Colony Formation Assays for JTK-853 in a Single}

\section{Treatment}

Prior to performing the colony formation assay to demonstrate that JTK-853 and DAAs did not show cytotoxicity, the compounds were added to the parental Huh7.5 cells without Geneticin for 2 weeks. The thumb pocket NNI-B and NS5Ai were added at $100 \mu \mathrm{M}$ and $100 \mathrm{nM}$, respectively. The JTK-853 and other DAAs were added at $10 \mu \mathrm{M}$. The results revealed no Huh-7.5 cell death was apparent at these concentrations in 2-week culture (fig. 1e). Therefore, the cell death observed in replicon cells in the presence of the DAAs with Geneticin would result from antiviral activity of the DAAs and not through cytotoxicity. Then, we conducted the colony formation assay to evaluate the emergence of drug resistance.

We investigated the genetic barrier of JTK-853 to resistance in HCV replicons of genotype $1 \mathrm{a} \mathrm{H77} \mathrm{and} 1 \mathrm{~b}$
Con 1 strains. To avoid the influence of preexisting drugresistant variants, the DAAs were applied for treatment at just $4 \mathrm{~h}$ after transfection of the HCV replicon RNAs into Huh-7.5 cells. The cells were treated with the palm site NNIs JTK-853 and GS-9190 at $1 \times \mathrm{EC}_{90}(\mathrm{H} 77)$ or $1 / 3 \times \mathrm{EC}_{90}$ (Con1) in the presence of $40 \% \mathrm{HS}$ and $600 \mu \mathrm{g} / \mathrm{ml}$ Geneticin. After 14-17 days of culture, the JTK-853- and GS-9190-resistant colonies were visualized by crystal violet staining. As shown in figure 1a, JTK-853 suppressed the drug-resistant colony formation in the genotype 1a replicon cells, and the numbers of JTK853-resistant colonies were much lower than those of GS-9190-resistant colonies for both genotypes. The dyed DAA-resistant colonies with crystal violet were lysed with the lysis buffer, and the OD value of the lysate was determined in order to quantify the emergence of the DAA-resistant colonies. The OD value of JTK-853-resistant colonies was $2.8 \%$ of the DMSO control in the genotype 1a replicon cells, while that of GS-9190-resistant colonies was $71 \%$ as shown in figure 1a and table 2 . In a similar fashion, JTK-853 suppressed the drug-resistant colony formation in the genotype $1 \mathrm{~b}$ replicon cells as shown in figure $1 \mathrm{~b}$ and table 2 . Sequence analyses revealed an amino acid substitution of L466V/I in NS5B in the JTK-853-resistant colonies, while Y448H in NS5B was detected in the GS-9190-resistant colonies. We previously demonstrated that $\mathrm{L} 466 \mathrm{~V}$ confers resistance to JTK-853 with more than 20 -fold reduced susceptibility in vitro [10], which is almost consistent with the colony formation assay results. On the other hand, $\mathrm{Y} 448 \mathrm{H}$ is known to be a resistance mutation for GS-9190 [13,25]. Without Geneticin selection, no cell death was apparent after treatment with JTK-853 and the DAAs, suggesting that the colonies consisted of cells harboring drug-resistant replicons. These findings demonstrate that JTK-853 shows a higher genetic barrier to resistance than the other palm site-binding NNI GS-9190 in genotypes 1a and $1 \mathrm{~b} \mathrm{HCV.}$

We also compared the genetic barrier of JTK-853 with those of other classes of DAAs using colony formation assays. After transfection of replicon RNA, the cells were treated with JTK-853, NNI-A, PF-868554, VX-222, PSI6130 , BMS-790052, or TMC435 at $1 / 3 \times \mathrm{EC}_{90}$ for $13-$ 17 days. The DAA-resistant colonies for genotype 1a H77 are shown in figure $1 \mathrm{c}$ and table 2 . The OD value of JTK853 -resistant colonies was 0.2 and $2.4 \%$ of the control, which was much lower than those of the other classes of NNIs, i.e. NNI-A, PF-868554, and VX-222. JTK-853 also showed a reduced number of resistant colonies compared with the NS5Ai BMS-790052, while the numbers of JTK- 


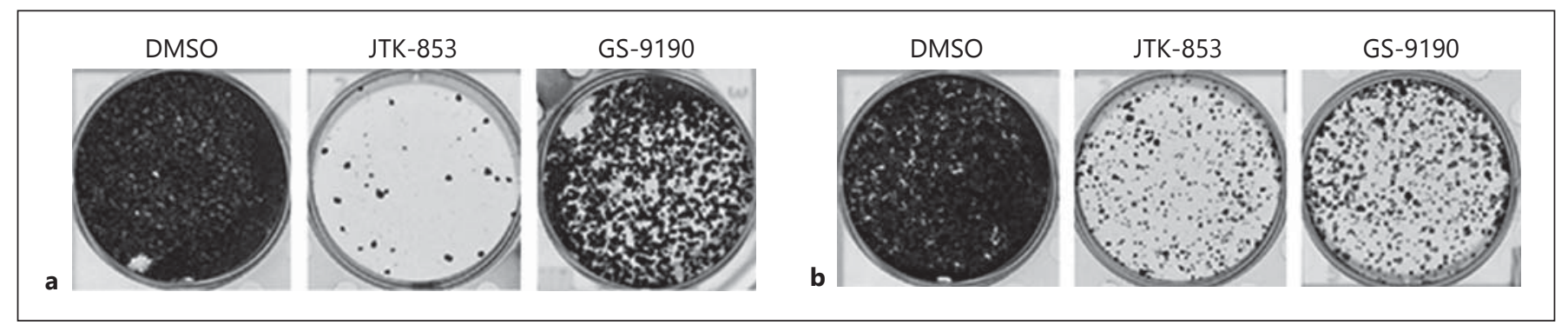

Fig. 1. Resistance barriers of JTK-853 for HCV genotype $1 \mathrm{a} \mathrm{H} 77$ and $1 \mathrm{~b}$ Con 1 in a single treatment. The JTK-853- or DAAcontaining medium was changed twice a week. a Genetic barriers of JTK-853 and GS-9190 for H77. JTK-853 and GS-9190 were treated at $1 \times \mathrm{EC}_{90}$ for 17 days. $\mathbf{b} \mathrm{Ge}$ netic barriers of JTK-853 and GS-9190 for Con1. JTK-853 and GS-9190 were treated at $1 / 3 \times \mathrm{EC}_{90}$ for 14 days. c, d Genetic barriers of JTK-853, NNI-A, PF-868554, VX222, PSI-6130, BMS-790052, and TMC435 for Con1. JTK-853 and the other DAAs were treated at $1 / 3 \times \mathrm{EC}_{90}$ for 17 days. Representative images from two experiments are shown.

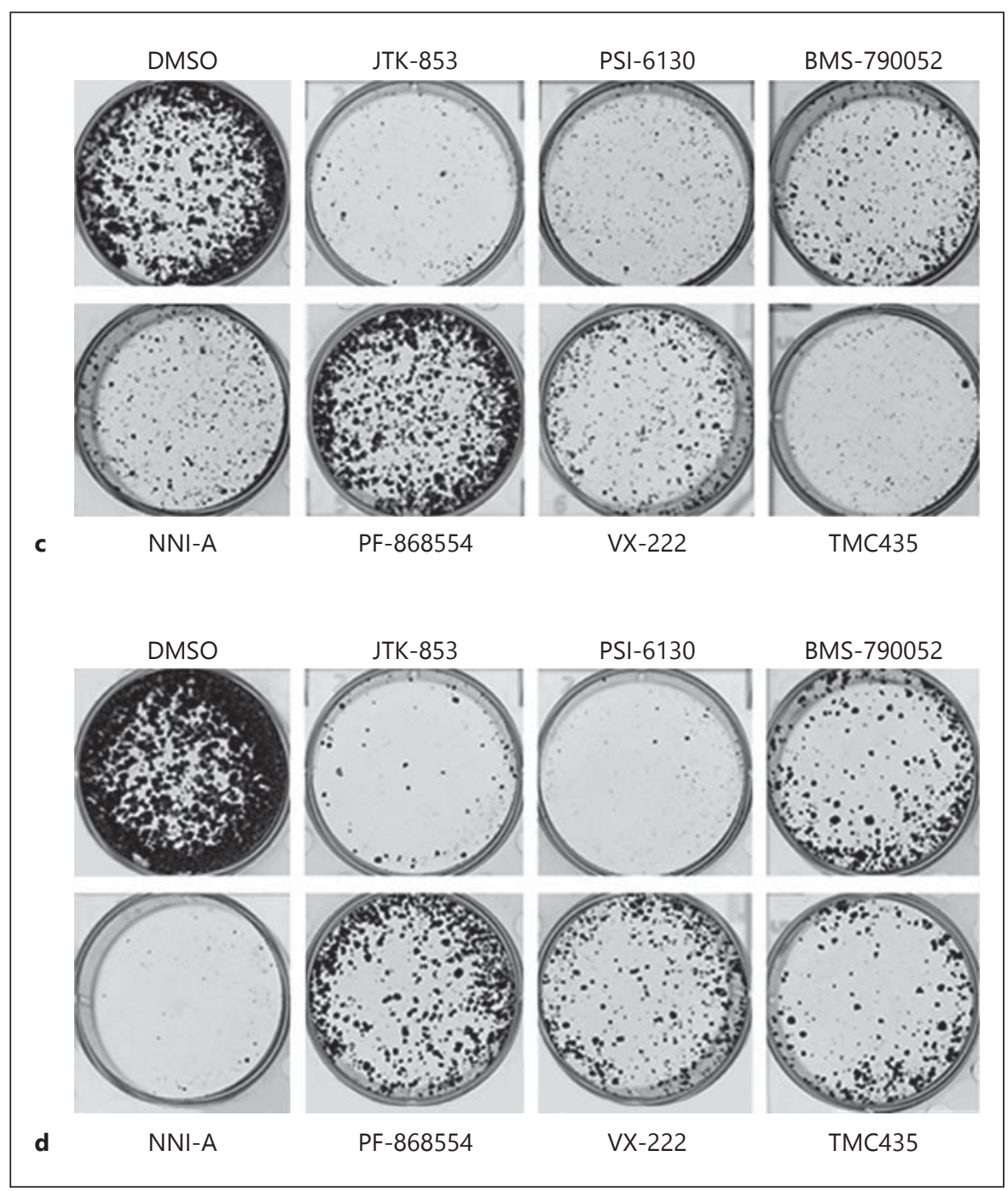

853-resistant colonies were as small as those for the NI PSI6130 and PI TMC435. Sequence analyses revealed an emergence of amino acid substitution of M414T in NS5B of JTK853-resistant colonies, while A499T, I482V, and L419M in NS5B of NNI-A-, PF-868554-, and VX-222-resistant colonies, respectively. In addition, the amino acid substitutions of P32S in NS5A in BMS-790052-resistant colonies and
V36A in NS3 in TMC435-resistant colonies were identified, respectively. These mutations are known to be resistance mutations to the corresponding DAAs $[10,13,14,16$, $21,26,27]$. These findings demonstrate that JTK- 853 shows a higher genetic barrier to resistance than the thumb pocket-binding NNIs and NS5Ai, and shows a high genetic barrier that is as potent as those of the NI and PI. 


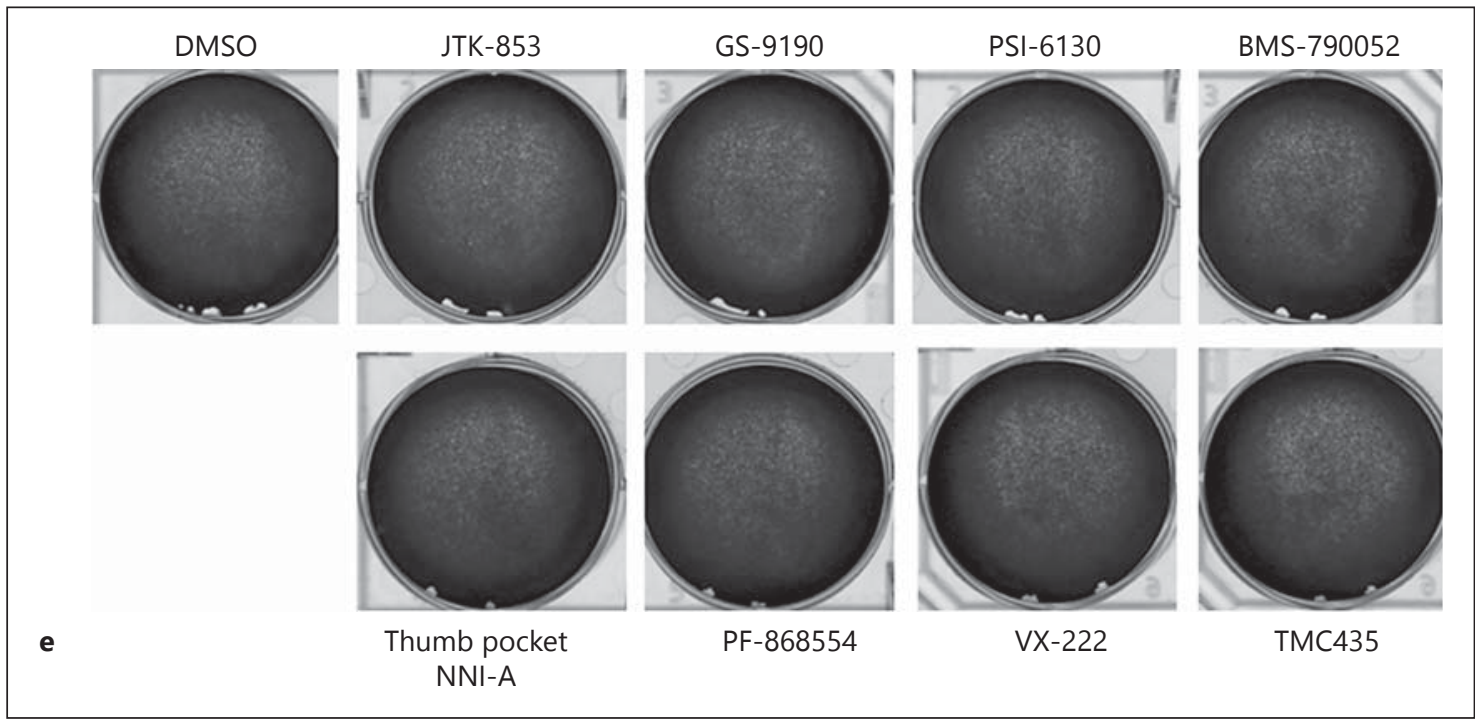

Fig. 1. e The cytotoxicity of JTK- 853 or other DAAs. The Huh-7.5 cells were treated with JTK-853 or other DAAs for 2 weeks. The thumb pocket NNI-B and NS5Ai were added at $100 \mu \mathrm{M}$ and $100 \mathrm{nM}$, respectively. JTK-853 and other DAAs were added at $10 \mu \mathrm{M}$. The cells were dyed with crystal violet [1\% (v/v) in methanol].

Table 2. In vitro barrier of JTK-853 to the resistance

\begin{tabular}{|c|c|c|c|c|c|c|}
\hline \multirow{2}{*}{$\begin{array}{l}\text { Direct-acting } \\
\text { antivirals }\end{array}$} & \multicolumn{3}{|l|}{ 1a (H77) } & \multicolumn{3}{|l|}{$1 \mathrm{~b}(\mathrm{Con} 1)$} \\
\hline & concentrations ${ }^{\mathrm{a}}$ & $\begin{array}{l}\text { OD } 595 \mathrm{~nm}(\% \text { of } \\
\text { DMSO control) }\end{array}$ & $\begin{array}{l}\text { amino acid } \\
\text { substitutions }^{c}\end{array}$ & concentrations ${ }^{\mathrm{a}}$ & $\begin{array}{l}\text { OD } 595 \mathrm{~nm}(\% \text { of } \\
\text { DMSO control })^{\mathrm{b}}\end{array}$ & $\begin{array}{l}\text { resistant } \\
\text { mutations }^{c}\end{array}$ \\
\hline JTK-853 & $1 \times \mathrm{EC}_{90}$ & 2.8 & L466I & $1 / 3 \times \mathrm{EC}_{90}$ & 7.6 & L466V \\
\hline GS-9190 & $1 \times \mathrm{EC}_{90}$ & 71 & $\mathrm{Y} 448 \mathrm{H}$ & $1 / 3 \times \mathrm{EC}_{90}$ & 13 & $\mathrm{Y} 448 \mathrm{H}$ \\
\hline JTK-853 & $1 / 3 \times \mathrm{EC}_{90}$ & 0.2 & M414T & $1 / 3 \times \mathrm{EC}_{90}$ & 2.4 & M414L \\
\hline NNI-A & $1 / 3 \times \mathrm{EC}_{90}$ & 3.8 & $\mathrm{~A} 499 \mathrm{~T}$ & $1 / 3 \times \mathrm{EC}_{90}$ & 1.1 & $-{ }^{\mathrm{d}}$ \\
\hline PF-868554 & $1 / 3 \times \mathrm{EC}_{90}$ & 85 & $\mathrm{I} 482 \mathrm{~V}$ & $1 / 3 \times \mathrm{EC}_{90}$ & 40 & $\mathrm{I} 482 \mathrm{~V}$ \\
\hline VX-222 & $1 / 3 \times \mathrm{EC}_{90}$ & 12 & L419M & $1 / 3 \times \mathrm{EC}_{90}$ & 17 & $-^{\mathrm{e}}$ \\
\hline PSI-6130 & $1 / 3 \times \mathrm{EC}_{90}$ & 1.4 & $-{ }^{\mathrm{d}}$ & $1 / 3 \times \mathrm{EC}_{90}$ & 1.3 & $-{ }^{\mathrm{d}}$ \\
\hline BMS-790052 & $1 / 3 \times \mathrm{EC}_{90}$ & 7.3 & P32S & $1 / 3 \times \mathrm{EC}_{90}$ & 20 & L31V \\
\hline TMC435 & $1 / 3 \times \mathrm{EC}_{90}$ & 0.5 & V36A & $1 / 3 \times \mathrm{EC}_{90}$ & 14 & D168E \\
\hline
\end{tabular}

${ }^{a}$ Concentrations used for colony formation assay.

${ }^{\mathrm{b}}$ Data represent relative values of the drug-resistant colonies to DMSO control for colony formation assay.

${ }^{c}$ Amino acid substitutions known to the resistant mutations corresponding to the DAAs.

d Sequence analysis was not performed because of small number of colonies.

e Amino acid substitutions known to the resistant mutations were not detected.

The DAA-resistant colonies for genotype $1 \mathrm{~b}$ Con 1 are shown in figure $1 \mathrm{~d}$ and table 2 . The number of JTK853-resistant colonies was much lower than those of the other DAAs, such as PF-868554, VX-222, BMS-790052, and TMC435, but slightly higher than those of PSI-6130 and NNI-A. Amino acid substitutions of M414L in NS5B, I482V in NS5B, L31V in NS5A, and D168E in NS3 were identified in the JTK-853-, PF-868554-, BMS790052-, and TMC435-resistant colonies, respectively. These mutations are known to confer resistance to the corresponding DAAs $[10,14,16,17]$. These data demonstrate that JTK-853 also shows a higher genetic barrier to resistance than the DAAs for genotype $1 \mathrm{~b}$ $\mathrm{HCV}$. 


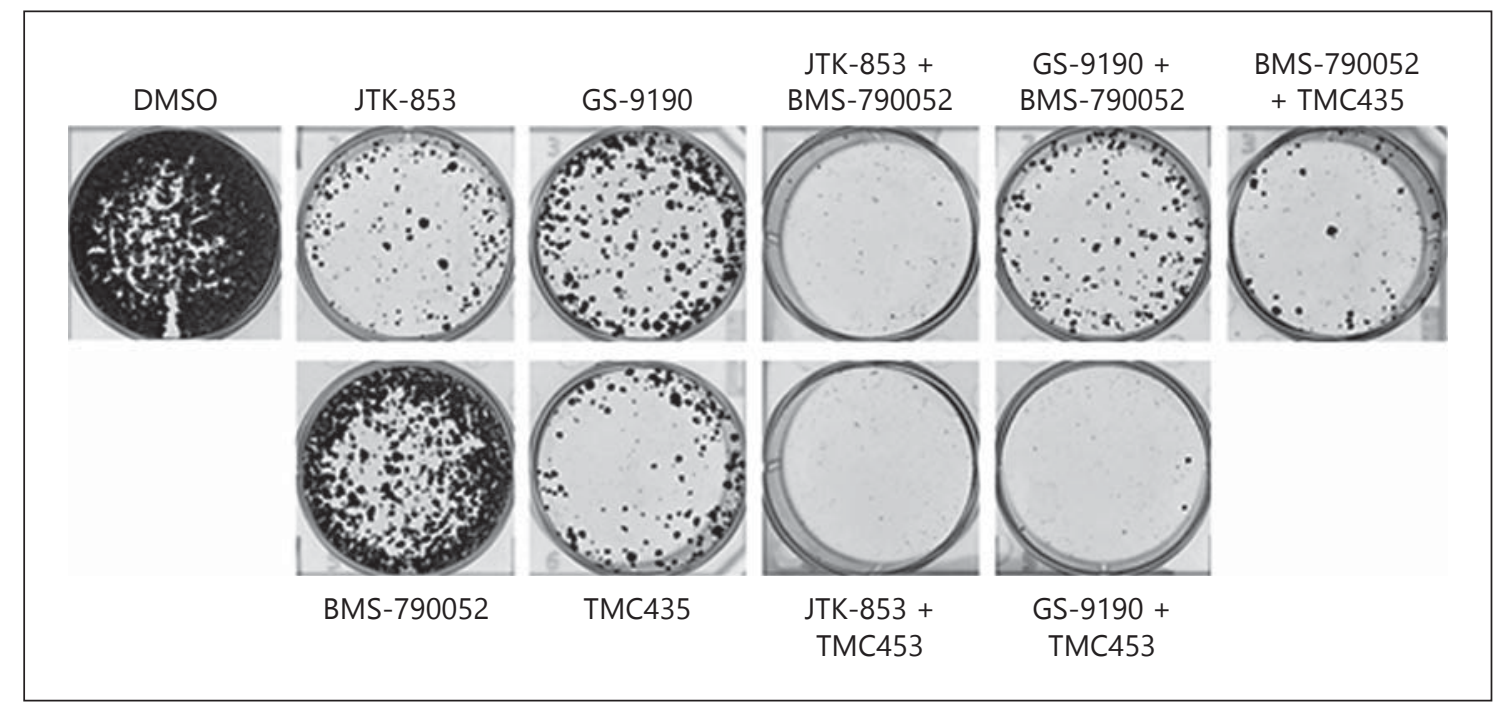

Fig. 2. Resistance barriers of JTK-853 in combination with BMS-790052 or TMC435. HCV replicons of genotype 1a H77 strain were treated at $1 / 4 \times \mathrm{EC}_{90}$ for 19 days. The JTK-853- or DAA-containing medium was changed twice a week. Representative images from two experiments are shown.

Thus, these findings demonstrate that JTK-853 also shows a higher genetic barrier to resistance than some different classes of DAAs for genotype 1a and $1 \mathrm{~b} \mathrm{HCV}$.

\section{Colony Formation Assays of JTK-853 in Combination} with DAAs

Next, we conducted colony formation assays of JTK853 in combination with DAAs for genotype 1a HCV. After transfection of the replicon RNA, the cells were treated with JTK-853 in combination with BMS-790052 or TMC435 at $1 / 4 \times \mathrm{EC}_{90}$, respectively. As shown in figure 2, the numbers of resistant colonies after treatment with JTK-853 in combination with BMS-790052 or TMC435 were lower than those after treatment with JTK853 alone. Moreover, the number of resistant colonies after treatment with JTK-853 in combination with BMS790052 was lower than those after treatment with BMS790052 in combination with GS-9190 or TMC435, while JTK-853 suppressed the emergence of drug-resistant colonies as potently as GS-9190 in combination with TMC435. Amino acid substitutions of Q41R in NS3 and $\mathrm{M} 28 \mathrm{~V}$ in NS5A were identified in the resistant colonies treated with TMC435 + BMS-790052 and GS-9190 + BMS-790052, respectively. Regarding the treatments with JTK-853 + BMS-790052, JTK-853 + TMC435, and GS$9190+$ TMC435, sequence analyses could not be performed because of the very low numbers of resistant colonies. These findings demonstrate that JTK- 853 shows a higher genetic barrier to resistance than the other palm site NNI, GS-9190, even in combination with an NS5Ai (BMS-790052) or a PI (TMC435).

\section{Discussion}

In vitro selection studies and colony formation assays are thought to be useful for estimating resistance mutations and genetic barriers to resistance in clinical studies $[16,20,28-30]$. Actually, a high genetic barrier of an NI to resistance in vitro well reflects a low frequency of viral breakthrough or rebound during treatment of HCV-infected patients with the NI. On the other hand, NNI, NS5Ai, and PI showed low genetic barriers in both clinical and in vitro studies [30]. Therefore, the colony formation assay of JTK-853 is useful for estimating the genetic barrier of JTK-853 to resistance. Although NNIs are generally considered to show low genetic barriers to resistance, JTK853 showed a high genetic barrier to resistance in vitro. The number of JTK-853-resistant colonies was much lower than those of the other NNIs. In addition, Y448H, a persistent mutation, was not observed in the JTK-853-resistant colonies. Therefore, JTK-853 appeared to show a high genetic barrier, which differs greatly from the other NNIs.

To identify more potent regimens for antiviral activity and higher genetic barriers, combinations of two or more DAAs have been evaluated in clinical studies [31-33]. 
Combination treatments showed more potent antiviral effects than single treatments, but it remains unclear which combinations are effective for high genetic barriers in clinical studies. In fact, treatment with BMS-790052 (NS5Ai) in combination with BMS-650032 (PI) in HCVinfected patients frequently showed viral rebound during the treatment [31]. Consistently, drug-resistant colonies emerged in combination treatments with BMS-790052 (NS5Ai) + GS-9190 (NNI) and BMS-790052 + TMC435 (PI) in our in vitro colony formation assays. Interestingly, JTK-853 in combination with BMS-790052 or TMC435 completely suppressed the emergence of drug-resistant colonies in our study, and a high genetic barrier of JTK853 was more distinct in the combination treatments than in the single treatments. Taken together, JTK-853 will show a high genetic barrier in clinical studies, especially in combination treatments.

Recently, we reported the co-crystal structure of JTK853 with HCV polymerase [10]. The binding mode of JTK-853 to HCV polymerase is characteristic and clearly distinct from that of other palm site-binding HCV polymerase inhibitors in the aspect of binding to the $\beta$-hairpin region and palm I site of HCV polymerase $[14,18]$. This unique binding mode of JTK-853 possibly leads to the high genetic barrier.

Collectively, this study has demonstrated that JTK-853 shows a higher genetic barrier to resistance than the other NNIs, PI, and NS5Ai examined. JTK-853 exhibits a promising profile with its unique ability to inhibit the emergence of viral resistance.

\section{Acknowledgments}

We acknowledge Yasumasa Komoda and all members of the HCV project team at the Japan Tobacco Biological/Pharmacological Research Laboratories of Central Pharmaceutical Research Institute (Takatsuki, Osaka, Japan) for their technical advice and assistance, and Kazuyuki Sugimoto and Hiroyuki Abe for the preparation of the DAAs. We also thank Gabriela Turcanu, Sudhakar Pai, and Barbara Gerhardt for coordinating the project.

\section{References}

$>1$ Alter MJ: Epidemiology of hepatitis C virus infection. World J Gastroenterol 2007;13: 2436-2441.

-2 Takamizawa A, Mori C, Fuke I, Manabe S, Murakami S, Fujita J, Onishi E, Andoh T, Yoshida I, Okayama H: Structure and organization of the hepatitis $\mathrm{C}$ virus genome isolated from human carriers. J Virol 1991;65:11051113.

>3 Tong CYW, Gilmore IT, Hart CA: HCV-associated liver cancer. Lancet 1995;345:10581059.

4 Pawlotsky JM: Treatment failure and resistance with direct-acting antiviral drugs against hepatitis C virus. Hepatology 2011;53: 1742-1751.

5 Gane EJ, Stedman CA, Hyland RH, Sorensen RD, Symonds WT, Hindes R, Berrey MM: Once daily PSI-7977 plus RBV: pegylated interferon-ALFA not required for complete rapid viral response in treatment-naïve patients with HCV GT2 or GT3. 62nd Annual Meeting of the American Association for the Study of Liver Diseases (AASLD). Hepatology 2011;54(suppl):377A.

6 Lawitz E, Lalezari JP, Hassanein T, Kowdley KV, Poordad FF, Sheikh AM, Afdhal NH, Bernstein DE, DeJesus E, Freilich B, David R, Nelson DR, Dieterich DT, Jacobson IM, Jensen DM, Abrams GA, Darling JM, RodriguezTorres M, Reddy KR, Sulkowski MS, Bzowej NH, DeMicco MP, Strohecker JS, Hyland RH, Mader M, Albanis E, Symonds WT, Berrey MM: Once-daily PSI-7977 plus Peg/RBV in treatment-naïve patients with HCV GT1: robust end of treatment response rates are sustained post-treatment. 62nd Annual Meeting of the American Association for the Study of Liver Diseases (AASLD). Hepatology 2011; 54(suppl):472A.

7 Rodriguez-Torres M, Lalezari J, Gane EJ, DeJesus E, Nelson DR, Everson GT, Jacobson IM, Reddy KR, McHutchison JG, Beard A, Walker S, Symonds W, Berrey MM: Potent antiviral response to the $\mathrm{HCV}$ nucleoside polymerase inhibitor R7128 for 28 days with peg-IFN and ribavirin: subanalysis by race/ ethnicity, weight and HCV genotype. 59th Annual Meeting of the American Association for the Study of Liver Diseases (AASLD). Hepatology 2008;48(suppl):301A.

8 Lohmann V, Körner F, Koch J, Herian U, Theilmann L, Bartenschlager R: Replication of subgenomic hepatitis C virus RNAs in a hepatoma cell line. Science 1999;285:110-113.

-9 Graham EJ, Hunt R, Shaw SM, Pickford C, Hammond J, Westby M, Targett-Adams P: Colony-forming assays reveal enhanced suppression of hepatitis $\mathrm{C}$ virus replication using combinations of direct-acting antivirals. J Virol Methods 2011;174:153-157.

10 Ando I, Adachi T, Ogura N, Toyonaga Y, Sugimoto K, Abe H, Kamada M, Noguchi T: Preclinical characterization of JTK-853, a novel non-nucleoside inhibitor of the hepatitis $\mathrm{C}$ virus RNA-dependent RNA polymerase. Antimicrob Agents Chemother 2012;56:42504256.
11 Rodriguez-Torres M, Pai S, Gerhardt B, Yamada H, Yee K, Shibata T, Turcano G, Ogura N, Toyonaga Y, Noguchi T: Antiviral activity, safety and pharmacokinetics of JTK853, a novel non-nucleoside polymerase inhibitor, in a 3-day proof-of-concept study in HCV genotype 1 patients, and evaluation of emergence of resistance. HEP DART 2011: Front Drug Dev Viral Hepatitis, 2011, abstract 57.

12 Abe H, Tanaka M, Sugimoto K, Suma A, Yokota M, Shiozaki M, Iio K, Ueyama K, Motoda D, Noguchi T, Adachi T, Tsuruha J: Novel piperazine compound, and use thereof as $\mathrm{HCV}$ polymerase inhibitor. WIPO Patent Application WO/2007/119889, April 2007.

13 Shih IH, Vliegen I, Peng B, Yang H, Hebner C, Paeshuyse J, Pürstinger G, Fenaux M, Tian Y, Mabery E, Qi X, Bahador G, Paulson M, Lehman LS, Bondy S, Tse W, Reiser H, Lee WA, Schmitz U, Neyts J, Zhong W: Mechanistic characterization of GS-9190 (Tegobuvir), a novel nonnucleoside inhibitor of hepatitis C virus NS5B polymerase. Antimicrob Agents Chemother 2011;55: 4196-4203.

-14 Shi ST, Herlihy KJ, Graham JP, Nonomiya J, Rahavendran SV, Skor H, Irvine R, Binford S, Tatlock J, Li H, Gonzalez J, Linton A, Patick AK, Lewis C: Preclinical characterization of PF-00868554, a potent nonnucleoside inhibitor of the hepatitis $\mathrm{C}$ virus RNA-dependent RNA polymerase. Antimicrob Agents Chemother 2009;53:2544-2552. 
15 Ali S, Leveque V, Le Pogam S, Ma H, Philipp F, Inocencio N, Smith M, Alker A, Kang H, Najera I, Klumpp K, Symons J, Cammack N, Jiang WR: Selected replicon variants with low-level in vitro resistance to the hepatitis $\mathrm{C}$ virus NS5B polymerase inhibitor PSI-6130 lack cross-resistance with R1479. Antimicrob Agents Chemother 2008;52:4356-4369.

-16 Fridell RA, Qiu D, Wang C, Valera L, Gao M: Resistance analysis of the hepatitis $\mathrm{C}$ virus NS5A inhibitor BMS-790052 in an in vitro replicon system. Antimicrob Agents Chemother 2010;54:3641-3650.

17 Lenz O, Verbinnen T, Lin TI, Vijgen L, Cummings MD, Lindberg J, Berke JM, Dehertogh $\mathrm{P}$, Fransen E, Scholliers A, Vermeiren K, Ivens T, Raboisson P, Edlund M, Storm S, Vrang L, de Kock H, Fanning GC, Simmen KA: In vitro resistance profile of the hepatitis $\mathrm{C}$ virus NS3/4A protease inhibitor TMC435. Antimicrob Agents Chemother 2010;54:1878-1887.

-18 Ikegashira K, Oka T, Hirashima S, Noji S, Yamanaka H, Hara Y, Adachi T, Tsuruha J, Doi S, Hase Y, Noguchi T, Ando I, Ogura N, Ikeda S, Hashimoto H: Discovery of conformationally constrained tetracyclic compounds as potent hepatitis C virus NS5B RNA polymerase inhibitors. J Med Chem 2006;49:6950-6953.

19 Oka T, Ikegashira K, Hirashima S, Yamanaka H, Noji S, Niwa Y, Matsumoto Y, Sato T, Ando I, Nomura Y: Fused heterotetracyclic compounds and use thereof as HCV polymerase inhibitor. WIPO Patent Application WO/2005/080399, February 2005.

20 Rodriguez-Torres M, Lawitz E, Conway B, Kaita K, Sheikh AM, Ghalib R, Adrover R, Cooper C, Silva M, Rosario M, Bourgault B, Proulx L, McHutchison JG: Safety and antiviral activity of the HCV nonnucleoside polymerase inhibitor VX-222 in treatment-naïe genotype 1 HCV-infected patients. 45th Annual Meeting of the European Association for the Study of theLiver(EASL).JHepatol2010;52(suppl):S62.
21 Yi G, Deval J, Fan B, Cai H, Soulard C, Ranjith-Kumar CT, Smith DB, Blatt L, Beigelman L, Kao CC: Biochemical study of the comparative inhibition of hepatitis $\mathrm{C}$ virus RNA polymerase by VX-222 and filibuvir. Antimicrob Agents Chemother 2012;56:830-837.

22 Blight KJ, McKeating JA, Marcotrigiano J, Rice CM: Efficient replication of hepatitis $\mathrm{C}$ virus genotype 1a RNAs in cell culture. J Virol 2003;77:3181-3190.

23 Krieger N, Lohmann V, Bartenschlager R: Enhancement of hepatitis $C$ virus RNA replication by cell culture-adaptive mutations. J Virol 2001;75:4614-4624.

24 Lohmann V, Hoffmann S, Herian U, Penin F, Bartenschlager R: Viral and cellular determinants of hepatitis $C$ virus RNA replication in cell culture. J Virol 2003;77:3007-3019.

25 Hebner C, Harris J, Oldach D, Miller MD, Mo $\mathrm{H}$ : Emergence and persistence of NS5B mutations following combination treatment with tegobuvir (GS-9190) plus standard of care long-term follow-up from the phase IIb study GS-US-196-0103. 46th Annual Meeting of the European Association for the Study of the Liver (EASL). J Hepatol 2011;4(suppl):S478.

26 Howe AY, Cheng H, Thompson I, Chunduru SK, Herrmann S, O'Connell J, Agarwal A, Chopra R, Del Vecchio AM: Molecular mechanism of a thumb domain hepatitis $C$ virus nonnucleoside RNA-dependent RNA polymerase inhibitor. Antimicrob Agents Chemother 2006;50:4103-4113.

27 Kukolj G, McGibbon GA, McKercher G, Marquis M, Lefèbvre S, Thauvette L, Gauthier J, Goulet S, Poupart MA, Beaulieu PL: Binding site characterization and resistance to a class of non-nucleoside inhibitors of the hepatitis C virus NS5B polymerase. J Biol Chem 2005;280:39260-39267.

28 Nettles RE, Gao M, Bifano M, Chung E, Persson A, Marbury TC, Goldwater R, DeMicco MP, Rodriguez-Torres M, Vutikullird A, Fuentes E, Lawitz E, Lopez-Talavera JC, Grasela DM: Multiple ascending dose study of BMS790052, a nonstructural protein 5A replication complex inhibitor, in patients infected with hepatitis C virus genotype 1. Hepatology 2011; 54:1956-1965.
29 Reesink HW, Fanning GC, Farha KA, Weegink C, Van Vliet A, Van 't Klooster G, Lenz $\mathrm{O}$, Aharchi F, Mariën K, Van Remoortere P, De Kock H, Broeckaert F, Meyvisch P, Van Beirendonck E, Simmen K, René Verloes R: Rapid HCV-RNA decline with once daily TMC435: a phase I study in healthy volunteers and hepatitis $\mathrm{C}$ patients. Gastroenterology 2010;138:913-921.

30 Sarrazin C, Zeuzem S: Resistance to direct antiviral agents in patients with hepatitis $C$ virus infection. Gastroenterology 2010;138:447-462.

31 Lok A, Gardiner D, Hézode C, Lawitz E, Bourlière M, Everson G, Marcellin P, RodriguezTorres M, Pol S, Serfaty L, Eley T, Huang SP, Wind-Rotolo M, McPhee F, Grasela D, Pasquinelli C: Confirmation that quadruple therapy with daclatasvir (NS5a inhibitor), asunaprevir (NS3 inhibitor) and peginterferon/ribavirin results in high rate of SVR4 in HCV genotype 1 null responders. 47th Annual Meeting of the European Association for the Study of the Liver (EASL). J Hepatol 2012;56(suppl):S557.

32 Soriano V, Gane E, Angus P, Stickel F, Bronowicki JP, Roberts S, Manns M, Zeuzem S, Dai L, Boecher W, Stern J, Mensa F: The efficacy and safety of the interferon-free combination of bi201335 and bi207127 in genotype 1 HCV patients with cirrhosis - interim analysis from sound-c2. 47th Annual Meeting of the European Association for the Study of the Liver (EASL). J Hepatol 2012;56(suppl):S559.

33 Sulkowski M, Gardiner D, Lawitz E, Hinestrosa F, Nelson D, Thuluvath P, Rodriguez-Torres $\mathrm{M}$, Lok A, Schwartz H, Reddy KR, Eley T, Wind-Rotolo M, Huang SP, Gao M, McPhee F, Hindes R, Symonds B, Pasquinelli C, Grasela D: Potent viral suppression with all-oral combination of daclatasvir (NS5A inhibitor) and GS-7977 (NS5B inhibitor), +/-ribavirin, in treatment-naïve patients with chronic $\mathrm{HCV}$ GT1, 2, or 3. 47th Annual Meeting of the European Association for the Study of the Liver (EASL). J Hepatol 2012;56(suppl):S560. 